\title{
Social Accountability in War Zones - Confronting Local Realities of Law and Justice
}

\author{
Anna Macdonald \\ Fellow, Department of International Development, London School of \\ Economics, London, UK \\ a.macdonaldı@lse.ac.uk \\ Tim Allen \\ Professor, Department of International Development, London School of \\ Economics, London, $\mathrm{UK}$ \\ t.allen@lse.ac.uk
}

\begin{abstract}
This article examines how justice and social order are administered and experienced in poor, politically fragile and conflict-affected environments. Taking notions of legal pluralism and public authority as our starting point, we explore how moral and social worlds are understood in places where 'the law' is not necessarily a discrete institutionalised process. Drawing upon current debates in the field, as well as findings from the six articles in this special issue, we explore how legal pluralism and public authority operate in context; how we might evaluate whether 'justice' is being done'; and the stark dissonances between local realities and the normative assumptions that currently guide international development interventions, particularly around rule-of-law reform and access to justice initiatives.
\end{abstract}

\section{Keywords}

legal pluralism - public authority - social accountability - rule of law - access to justice 
How people living in the world's most difficult places - the poorest, most politically fragile and conflict-affected environments - seek redress, justice and social order is important both for them and for the world as a whole. And yet we know remarkably little about everyday, lived realities in these places. There exists a gaping information vacuum. As such, important international policies on issues such as expanding 'access to justice' or promoting the 'rule of law' are devised and implemented on the basis of norms and assumptions rather than on evidence and careful analysis. This special issue contributes to existing knowledge in this area with six pieces of fine-grained ethnographic research that help us understand how justice and social order are regulated in conflict-affected places that remain beyond the reach of institutional governance or at its margins. Our cases are mainly concentrated in central Africa: eastern Democractic Republic of Congo (DRC), northern Uganda and South Sudan. There is also an article on Timor-Leste. Unsurprisingly much analysis of law and justice, even when the focus is on local realities, is imbued with normative agendas about what law and justice should look like and also, normatively driven agendas about what local realities should look like. ${ }^{2}$ The combination of the two, all these articles suggest, results in a situation in which things that are not really hidden from view are nevertheless not seen. This collection of articles is about that tension and it explores ways in which those unseen processes might be incorporated into analysis.

In all contexts our authors examine how the lived experience of 'public authority' relates to the provision of social accountability. 'Public authority' is understood here as the organisation of social life, at a greater level than the family, so as to allow individuals and groups to cooperate in activities. ${ }^{3}$ Just as it is everywhere, in the contexts under study, the existence of some form of public authority is the baseline for regulated social life, including the provision of public goods such as justice and social

1 Thank you to Rachel Ibreck, Mary Kaldor, Tom Kirk, Holly Porter, Henry Radice and Judith Verweijen for comments on earlier drafts of this article.

2 For an analysis of normative agendas in international policy on justice issues see T. Allen and A. Macdonald, 'Post-Conflict Traditional Justice', in G. Bruinsma and D. Weisburd (eds.), Encyclopedia of Criminology and Criminal Justice (Springer, New York, 2014) pp. 3831-3843; A. Macdonald, 'From the Ground-Up: What Does the Evidence Tell Us About Local Experiences of Transitional Justice?', 3:1 Transitional Justice Review (2015) pp. 72-121.

3 See O. Fjeldstad and M. Moore, 'Revenue Authorities and Public Authority in Sub-Saharan Africa', 47:1 Journal of Modern African Studies (2009) pp. 1-18. For a good overview of the concept of public authority and related debates, see K. Hoffmann and T. Kirk, 'Public Authority and the Provision of Public Goods in Conflict-Affected and Transitioning Regions', 7 Justice and Security Research Programme (2013). 
order. Below we elaborate on how this relates to existing definitions of the term and the power relations at play in any given situation. This takes us in a very different direction to debates which make a conceptual link between 'law' and stability and the idea of functioning and mal-functioning states because while public authority may involve state officials and formal legal procedures, it is more likely to include a host of other actors, including traditional chiefs, spiritual authorities, international aid agencies, militia leaders, entrepreneurs, age-set meetings and vigilante groups. At the local level, people may have recourse to normative processes that stand in tension with one another, for example forms of Pentecostal Christianity that openly reject traditional ritual practice. There are also forms of social accountability that incorporate local or customary notions about the allocation of personal responsibility for suffering, perhaps through the idiom of witchcraft. Other systems that are present may include 'hybrids', combining aspects of formal and informal governance institutions and norms. The aim of the issue is to discuss the lived realities of social accountability set in the context of a detailed empirical picture of contemporary life under complex and pluralistic forms of public authority.

In this introductory article, we relate insights from the articles that follow to debates within the literature on legal pluralism, public authority, theories of justice and rule of law development, and comment upon some of the contradictions and challenges that are worthy of further theoretical and empirical consideration. In the first section we challenge what we view as the unhelpful over-emphasis on European colonialism in the legal pluralism literature, which misleadingly suggests that societies only became legally pluralistic when the colonial state-building project began from the sixteenth century onwards. Rather than focus on understandings of legal pluralism grounded in Weberian notions of law, which elide legal development with the state, we re-direct attention to law and rules as perennial "modes of thought" and a "manner of imagining the real". ${ }^{4}$ Thus, we explore how the moral world is understood in places where 'the law' is not necessarily a discrete institutionalised process, but rather comprises sets of rules and homilies conferred in a discretionary manner by a range of public authorities, from village elders to local vigilante groups. ${ }^{5}$ These rules comprise 'law' in so far as they are used to order the way

4 C. Geertz, Local Knowledge: Further Essays in Interpretive Anthropology (Basic Books, New York, 1983); See also H. Skoda, 'A Historians Perspective on the Present Volume', in P. Dresch and H. Skoda (eds.), Legalism: Anthropology and History (Oxford University Press, Oxford, 2012) pp. 39-54; P. Dresch, 'Legalism, Anthropology and History: A View From Part of Anthropology', in P. Dresch and H. Skoda (eds.), Legalism: Anthropology and History (Oxford University Press, Oxford, 2012) pp. 1-38.

5 Dresch, supra note 4, pp. 1-2; C. Sage and M. Woolcock, 'Introduction', in B. Tamanaha et al., Legal Pluralism and Development: Scholars and Practitioners in Dialogue (Cambridge University Press, Cambridge, 2013) pp. 1-21. 
in which a society behaves, and yet they may not be written down; are applied fluidly; and often draw a great deal of legitimacy from cosmologies that cannot be empirically verified. Thus in any given situation, the exact constellation of power and of societal dynamics is, at best, "pervasively indeterminate" and should be understood as such. ${ }^{6}$

In the second section, we explore in more detail the idea of 'public authority': the actual entities and institutions that mediate and regulate social order. All contexts under study comprise 'hybrids' of formal systems (institutions of internationally recognised governments) and informal systems based on combinations of patronage, kinship and religion. For hundreds of millions of people living in fragile and conflict-affected places, the latter represents the prevailing form of governance and these structures need to be better understood. In the third section we explore the notion of 'justice', and its connection with legal processes and what Kyed calls "order-making". It is not always clear that 'justice' is the standard which laws and rules are designed to meet. Indeed other public goods such as 'social harmony' are also sought by communities as the paramount imperative in responding to wrongdoing or settling disputes. ${ }^{8}$ So an important question arises around how we evaluate these processes, in other words, how do we form judgment about whether justice has been done? In the final section, we explore the often fantastical transformations that the international community aims to achieve in conflict-affected and fragile settings and the tangential relationship between international aspirations and local lived realities. In doing so, we examine some of the central tenets of ruleof-law policy and programming, including initiatives around 'access to justice'. We problematise orthodox approaches in this area, but also highlight new directions that might offer possibilities for more genuine and equitable reform.

For most of the world's population living in fragile or conflict-affected countries, social and political life is regulated in a multifarious domain of assorted

6 This point was made in a speech by a senior development official to a group of experts at the London School of Economics (LSE) in November 2014.

7 H. Kyed, State Recognition of Traditional Authority, Citizenship and State Formation in Rural Post War Mozambique (PhD Dissertation, Roskilde University, 2007) p. 6.

8 See H. Porter, 'Justice and Rape on the Periphery: The Supremacy of Social Harmony in the Space Between Local Solutions and Formal Judicial Systems in Northern Uganda', 6:1 Journal of Eastern African Studies (2012) pp. 85-86. 
and diverse rule systems and institutions - some public, some private, some hybrid - which enjoy varying degrees of "authority, legitimacy, coherence and capacity", depending on the issue at hand. ${ }^{9}$ In the following section we explore what this means in practice and examine some of the tensions that arise from the social reality of legal and normative pluralism in the contexts under study.

"Jurisdictional complexity" is hardly a condition unique to modern times. Throughout history, societies have operated under "remarkable jumbles of different sorts of law and institutions". ${ }^{10}$ As Brian Tamanaha argues, in the West, "the fact that we have tended to view law as a monopoly of the state is a testimony to the success of the state-building project and the ideological views which supported it", a project which began in the late medieval period. ${ }^{11}$ Thus perhaps too often, we associate the notion of legal pluralism with the emergence of colonialism and the rapid exportation from the sixteenth to the twentieth centuries of legal systems from Europe and North America to Latin America, Asia and Africa. ${ }^{12}$ While it is true that colonialism and the introduction of the modern, secular state may have created a very complicated and highly unequal legacy of legal pluralism in the contexts under study, it did not introduce plurality per se..$^{13}$ In terms of the cases being discussed here, for example, we have different forms of law dictating the incorporation of populations into the central African kingdoms such as Bunyoro; the spread of Islam; the incursions of armies from Egypt dating back to the nineteenth century; and the consequences of slave raiding and invasions by pastoralist groups.

Nevertheless, when thinking about legal pluralism today, there remains a strong temptation to tie, conceptually, notions of law, power and the state, but also to view indigenous non-state law as subordinate to the official law of the state. ${ }^{14}$ As the articles in this volume show, different forms of law in any given setting, are transacted in a manner that suggest that something far more complex is going on than a straight-forward desire for top-down control. Often, for example, law and rules are used rather vaguely and broadly by societies to make and re-make themselves; to draw up or substantiate social frameworks drawing

$9 \quad$ Sage and Woolcock, supra note 5, p. 1.

10 B.Z. Tamanaha, 'Understanding Legal Pluralism: Past to Present, Local to Global', 30 Sydney Law Review (2007) p. 377.

11 Ibid., p. 379.

12 S.E. Merry, 'Legal Pluralism and Legal Culture: Mapping the Terrain', in Tamanaha et al., supra note 5 , p. 67.

13 R. Michaels, 'Global Legal Pluralism', 5 Annual Review of Law and Social Science (2009) p. 4 .

14 Ibid., Skoda, supra note 4, p. $5^{\text {o. }}$ 
on their own 'archives of moral knowledge. ${ }^{15}$ Moreover, relationships within multi-centric legal and normative orders have never been static, thus, as Falk Moore argued in her work on Tanganika, the relationship between 'colonial' and 'indigenous' law was dynamic: "the paradox of directing change and preserving custom means that there can be no static concept of 'customary law". 16 Lauren Benton also emphasises the agency of indigenous colonial subjects in her argument that they were never simply the passive denizens of an imposed legal culture but that, across time and space, they were active in interpreting and making the law, and thus in shaping the international order. ${ }^{17}$ Tom Kirk's article in this issue provides a vivid account of the way in which the Timorese have actively hybridised governance arrangements to cope with colonisation, occupation and, more recently, liberal state-building. He points out that some Timorese, "refer to such practices as 'wrapping up' the old in the new" in order to construct contemporary institutions that deal with contemporary issues.

Given that social accountability relates to basic aspects of all collective and individual human behaviour, it is hardly surprising that the most fervid and unresolved question in the legal pluralism literature has been over how exactly 'law' should be defined. In the early to mid-twentieth century, anthropologists and anti-positivist legal philosophers observed that in colonial contexts, state law was often a remote factor in the normative structuring of society. Bronislav Malinowski's pioneering work, Crime and Custom in Savage Society, published in 1926 , was formative. ${ }^{18}$ As Wilson notes, "he argued that social norms in nonstate societies perform the same regulatory function as legal norms, thus non-codified social rules should be raised to the status of "law"'.19 This view became something of an orthodoxy among anthropologists but was soon under attack from a group of scholars called the 'legal centralists' who began querying the logical endpoint of legal pluralism. There was concern that by collapsing what they regarded to be the formally legal and the informally legal into one category of law, that category would be rendered meaningless. Legal

15 See e.g., W. James, The Listening Ebony: Moral Knowledge, Religion, and Power Among the Uduk of Sudan (Clarendon Press, Oxford, 1988) p. 340.

16 S.F. Moore, 'Treating Law as Knowledge: Telling Colonial Officers What to Say to Africans about Running 'Their Own' Native Courts', 26:1 Law and Society Review (1992) p. 16.

17 L. Benton, Law and Colonial Cultures:Legal Regimes in World History 1400-1900 (Cambridge University Press, Cambridge, 2002).

18 B. Malinowksi, Crime and Custom in Savage Society (Rowman and Littlefield, London, 1926).

19 R. Wilson, 'Tyrannosaurus Lex: The Anthropology of Human rights and Transnational Law' in M. Goodale and S. E. Merry (eds.), The Practice of Human Rights: Tracking the Law Between the Global and the Local (Cambridge University Press, Cambridge, 2007) p. 346. 
centralists emphasised the importance of distinguishing norms such as social etiquette from formal state law, namely that the latter is drafted and enacted by state apparatus and backed by enforcement powers in the military and criminal justice system. Brian Tamanaha's argument that law is a "folk concept" is helpful here. Having reviewed the intractable debate over how exactly 'law' should be defined, he concludes that "law is what people within social groups have come to see and label as law". 20

Manifestations of law within the same socio-political space may be manifold and while international law, state law, customary law, and religious law may not all share the same "basic characteristics", they share an important feature: they all claim "to represent legitimate authority" and are understood as such by those people who subscribe to them. ${ }^{21}$ As all articles in this issue clearly demonstrate, there are diverse ways in which societies "order a vision of the moral world and endow it with meaning".22 Rules are not always necessarily 'legal' in the sense that they represent a fixed body of law with associated sanctions, but they provide a "programme for living together" and a "public view of wrong, as distinct from private discomfort". 23 Thus, what constitutes 'law' in any given context is largely an empirical question.

As has been argued above, state and non-state forms of law and normative practice are rarely absolute categories, incommensurate with one another. Lauren Benton suggests that it is more helpful to view legal pluralism "as a multi-jurisdictional field rather than as a structure comprising multiple entities". ${ }^{24}$ People rarely see themselves as "occupying a fully separate normative order' that is 'in opposition to state law". ${ }^{25}$ Depending on circumstance, people - and communities - move between jurisdictions and authorities. ${ }^{26}$ In this issue, a terminology highlighted by both Naomi Pendle in her study of community policing in South Sudan and by Holly Porter in her examination of responses to rape in Northern Uganda, is the distinction people make between the "home people", "government people" and "the people of human rights" in the regulation of disputes. And yet, as all authors in the issue to some extent demonstrate, the boundaries between different jurisdictional entities: the

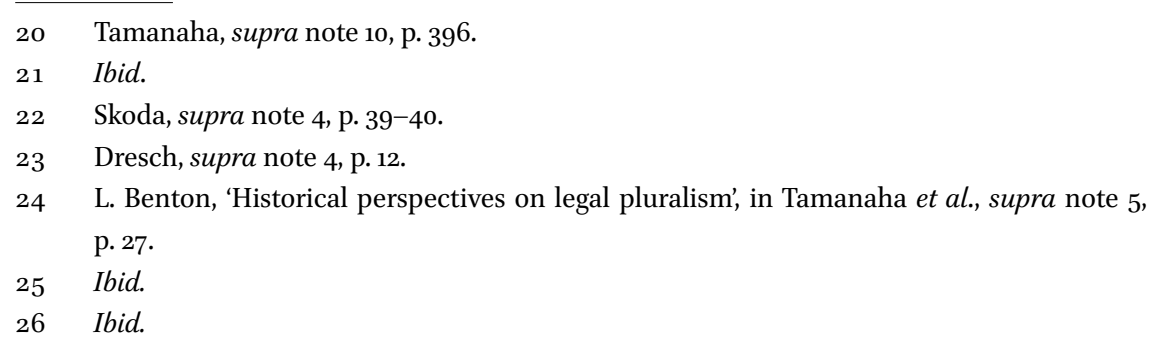


home; the church; and the state are never settled. We can, for example, observe a range of different interactions between even the most marginalised and vulnerable communities, and state law, symbols and authoritative language. In some cases this interaction is reminiscent of Benton's concept of "legal posturing" which, she argues, traverses jurisdictional boundaries and "flourishes in situations of supposed marginality". ${ }^{27}$ As we see in this volume, whether it be the titweng (cattle guard) in South Sudan importing and embracing the paraphernalia of state authority (uniforms, paychecks, new bureaucratic titles) or the women in northern Uganda who have been raped invoking human rights, despite knowing that they will probably not benefit from them, we can observe the different ways in which legal consciousness emerges as a result of terms and ideas derived from a "larger, universalising corpus". ${ }^{28}$ Perhaps this is an aspirational act, an attempt to transport local life into a "broader realm of civilization and rightful order". ${ }^{29}$ And yet it is important to point out that this is not the same as saying that the titweng can easily be transformed into state adjutants or that women in Acholiland can easily be transformed into idealtypical, self-actualising liberal subjects.

Even in refusing to accept state law and authority or in openly resisting it, people are acknowledging its presence and often expressing a dissatisfaction with the way in which legal procedures have been (or are likely to be) polluted by political interference or corruption. Julian Hopwood's study in this issue of the resolution of land disputes in northern Uganda provides an interesting example whereby even nominal state representatives in the form of local councillors reject formal legal processes and use locally grounded customary procedures to mediate between parties. Yet paradoxically, the very act of using prevalent notions of custom to resolve disputes gives credibility to the decisions of nominal state auxiliaries. Meanwhile, as Judith Verweijen (this issue) shows in the context of eastern DRC, the lack of due process in formal state-led dispute resolution has arguably led citizens to "similarly disregard procedures and standards of evidence" when incriminating others as part of local justice processes. Thus, as Salwar Ismail writes in the context of modern Egypt, the state is very much alive in people's imaginations and citizens "come to experience the state in the ways in which it does not exist for them, and not just the ways that it does". ${ }^{30}$ This is

27 L. Benton, A Search for Sovereignty: Law and Geography in European Empires, 1400-1900 (Cambridge University Press, Cambridge, 2010).

28 F. Pirie and J. Scheele, 'Introduction: Law, Justice and Community', in F. Pirie and J. Scheele (eds.), Legalism: Community and Justice (Oxford University Press, Oxford, 2014) p. 19.

29 Skoda, supra note 4, p. 3.

30 Quoted in S. J. Cooper-Knock, 'Policing in Intimate Crowds: Moving Beyond the 'Mob' in South Africa', 113:453 African Affairs (2014) p. 567. 
reminiscent of Јв White's argument that well defined legal categories enshrined in state law can "invite argument over the authority it defines.". ${ }^{31}$ Such debates might take place amongst intellectual elites concerned with the substantive nature of rights, but can also take place amongst the 'weak' and 'marginalised' in an effort to "articulate a claim to fairness and justice" or to assert the superiority of locally recognised order. ${ }^{32}$

All this begs the question: is legal pluralism something to worry about? There are opportunities and challenges inherent in legal pluralism in the context of fragile and conflict-affected places. The opportunities are quite practical in nature: where a state system is seen to be corrupt, inefficient or expensive, people are able to seek redress in a range of ways via authorities, institutions and rule-systems which are often trusted, but also accessible and comprehensible. But there are also significant challenges in these contexts. Let us highlight two that are raised by Sage and Woolcock. First is the absence or the weak nature of "meta-rules"; that is to say in places where there exists a patchwork of different regulatory systems, there is no preponderate authority that can credibly and legitimately mediate between contending orders. ${ }^{33}$ In most post-colonial states, customary law is recognised, but there also exists a constitution with a Bill of Rights. Goodfellow and Lindeman make the distinction between "institutional hybridity" characterised by "mutual adaptation and transformation" and "institutional multiplicity" characterised by "distinct and different normative frameworks and incentive structures". ${ }^{34}$ They argue that in situations of institutional multiplicity, institutional disputes, perhaps over land or decentralisation, can lead to violent outcomes. ${ }^{35}$ In northern Uganda for example, confusion and conflict over legal rights to land has led to violent clashes between communities who stress their customary right to ancestral land, and government troops who are trying to enforce the state's position that land which lies 'fertile but idle' should be sold to investors who have the capital to develop it.

Secondly, and linked to the above, while there is plenty of overlap between different legal and normative orders, these are often embedded in political and cosmological systems that are fundamentally 'incongruent', or, are 'fluid' and 'weak' and become 'overwhelmed.' ${ }^{36}$ The role that 'traditional' justice processes might play in broader transitional justice efforts illustrates this well and

\footnotetext{
31 Quoted in Pirie and Scheele, supra note 28, p. 10.

$32 \quad$ Ibid, p. 11.

33 Sage and Woolcock, supra note 5, p. 9.

34 T. Goodfellow and S. Lindemann, "The Clash of Institutions: Traditional Authority and the Failure of "Hybridity" in Bugunda', 51:1 Commonwealth and Comparative Politics (2013) p. 7.

$36 \quad$ Sage and Woolcock, supra note 5, p. 9.
} 
highlights a disconnect between international legal and human rights norms and locally legitimate processes of justice, accountability and reconciliation. ${ }^{37}$ From Afghanistan to Sierra Leone, studies have highlighted the persistent ethnic, religious, generational and gender hierarchies and divisions that complicate and limit the effectiveness of traditional practice from an international rights perspective. This is a point implicitly recognised in Kofi Annan's observation to the United Nations Security Council that the rule of law and transitional justice must be "in conformity with both international standards and local tradition". ${ }^{38}$ Legalist critics apply strict criteria in their assessment of community based justice processes and as such, institutions like the gacaca courts established to deal with the aftermath of the 1994 Rwanda genocide, have come under widespread criticism for an apparent failure to ensure due process, including, for example, professional representation and rules of evidence. ${ }^{39}$ This sort of legalist interpretation is misplaced, argues Phil Clark, because INGOs are wrongly interpreting gacaca as a "judicial institution that can be analysed through its governing legal documents", when in fact it's purpose was linked to much broader societal goals such as truth-telling and reconciliation. ${ }^{40}$ Indeed, across sites under study in this special issue, the tension between different normative and legal orders remains unresolved, and possible unresolvable. This was recognised by a Ugandan minister who explained to one of the authors in 2013 that "both formal and traditional justice will continue to exist but in an uncomfortable mixture". ${ }^{1}$

\section{3}

Public Authority and the Lived Realities of Social Accountability

In recent work in legal anthropology and ethnography, authors have directed our attention away from 'institutions' and particularly institutions of the state towards what Skoda calls a more "pluralist model", one in which:

37 See Allen and Macdonald supra note 2 for a full overview of this debate.

38 United Nations Secretary-General, 'The Rule of Law and Transitional Justice in Conflict and Post-Conflict Societies: Report of the Secretary-General to the Security Council' (s/2004/616). Human Rights Watch, Justice Compromised: The Legacy of Rwanda's Gacaca CommunityBased Courts (Human Rights Watch, New York, 2011).

40 P. Clark, The Gacaca Courts, Post Genocide Justice and Reconciliation in Rwanda: Justice Without Lawyers (Cambridge University Press, Cambridge, 2010).

41 A. Macdonald, Justice in Transition? Transitional Justice and its Discontents in Northern Uganda (PhD Thesis, King's College London, London, 2015). 
Jurisdiction is reconceptualised not as a bounded area within which legal authority can be exercised, but rather as the capacity to "speak the law", transforming our understanding of jurisdictional entities and institutions into a more subtle awareness of law as meaning, status and even charisma. $^{42}$

As noted above, a key critique of more expansive concepts of the 'law' and the 'legal' is that to exist as such, these categories must be clearly defined (preferably in written form) and must be able to demonstrate "public institutionalized enforcement of norms". ${ }^{3}$ The problem with this argument, as Tamanaha points out, is that a range of different institutions enforce norms and it is very difficult to determine which are 'public' and which are not. ${ }^{44}$ Secondly, throughout history and in the present day, societies have operated largely without institutionalised norm enforcement, despite clearly having a set of precedents and ideal normative principles that circumscribe a moral and social order: can we really argue, as legal theorist H.L.A. Hart did in the 196os, that such societies, "do not have law?"45

In the first section of this introductory article, we discussed the complex social reality of legal pluralism and argued that this was not $a$ priori a good or bad thing, but that it carried distinctive challenges in fragile and conflict-affected places. In this section, we aim to conceptualise this state of affairs in more depth, through an analysis of the co-existing and often overlapping entities, institutions and authorities that exercise and oversee security, law enforcement, legal judgment, and criminal punishment in the places under study.

There are two key ways of thinking about public authority in the contexts under study. The tension between approaches lies in whether we understand extant forms of public authority as part of longer term 'state-building' processes or, whether we try and understand these forms of governance as something qualitatively unique and unpredictable and thus as intrinsically important research subjects in their own right. While we certainly privilege the latter approach, it is important to understand scholarly developments related to the former. Kate Meagher has described a "paradigm shift" in the political science literature from "Weberian to Tillyan models" to describe processes of

\footnotetext{
42 Dresch, supra note 4, pp. 4-5.

43 Tamanaha, supra note 10, p. 392. Tamanaha points out that both Max Weber and Adam Hoebel define 'law' in these terms.

44 Ibid.

45 Ibid.
} 
state formation: ${ }^{46}$ While we may question the linearity and robustness of such a shift, it is certainly the case that research over the last decade or so has challenged prevailing assumptions that in the absence of western style governance institutions, fragile and conflict-affected societies collapse, flounder or eek by. New concepts emerged, most notably "governance without government", "negotiated" and "mediated" states and "hybrid political orders". ${ }^{47}$ This was in reaction to the inadequacies of the 'failed state' discourse on African governance that predominated in the 1990s and which drew a causal link between insecurity, under-development and the failure of states to "fulfil their core functions". ${ }^{48}$ The problem with this narrative, argued critics, was that even in places like Somalia and conflict-ravaged eastern DRC the lack of a functioning state had not resulted in complete breakdown; rather some level of basic service provision was still evident, even if it was not delivered by state authorities. This led to a burst of literature on hybrid forms of political authority in an attempt to understand the various ways in which non-state actors, ranging from customary authorities, to youth groups, to religious leaders, to businessmen, to militias were managing to deliver security, justice and other public goods in the absence of an effective state. ${ }^{49}$ The argument followed that the existence of multiple forms of order, even including violent vigilante groups in some cases, was productive rather than disastrous and may even contribute to longer-term state-building processes.

From a more practical perspective, these arguments have had important, albeit uneven, policy implications because conventional post-conflict statebuilding programmes are expensive and too often unsuccessful. Also, with the rise of 'resilience thinking', donors were increasingly acknowledging that the world was place of "radical uncertainty" and determined, in the words of the United Kingdom Department for International Development (DFID) to "embrace uncertainty as an opportunity ... to bounce back better". ${ }^{50}$ This underpinned an agenda to find a more cost-effective, more culturally 'embedded' forms of governance that donors could support; perhaps, as Menkhaus

46 K. Meagher, 'The Strength of Weak States? Non-State Security Forces and Hybrid Governance in Africa', 43:5 Development and Change (2012) p. 1073.

47 Ibid., p. 1074.

48 K. Hoffmann and T. Kirk, 'Public Authority and the Provision of Public Goods in ConflictAffected and Transitioning Regions', 7 Justice and Security Research Programme (2013) p. 3; K. Meagher et al., 'Unravelling Public Authority: Paths of Hybrid Governance in Africa', Is Academy Research Brief, 10 March 2014.

49 Meagher, supra note 46, p. 1075.

5o This is quoted in M. Duffield, 'Challenging Environments: Danger, Resilience and the Aid Industry', 43:5 Security Dialogue (2010) p. 7 . 
remarked, "local communities are not passive in the face of state failure and insecurity, but instead, adapt in a variety of ways to minimise risk and increase predictability in their dangerous environments". ${ }^{51}$ As such, scholars and policy makers are increasingly interested in local "arrangements that work" in fragile areas of the world, or places where the 'good governance' agenda has not taken root - although this does remain sector specific and often involves targeting funding towards certain NGOs specialised in 'grassroots' approaches. ${ }^{52}$

We are less concerned here with broader implications of current arrangements on longer-term state-building prospects and more interested in understanding exactly what such arrangements look like in the everyday political economies of conflict-affected and fragile places. Several scholars undertaking long-term, ethnographic and qualitative fieldwork have documented such processes empirically. In this issue, both Pendle and Verweijen show how in South Sudan and DRC respectively, non-state or hybrid militarised groups have played an important - and sometimes locally legitimate - role in regulating social order in the name of justice. Hopwood focuses on non-militarised public authorities in northern Uganda, but draws a similar conclusion that local public authorities, who often amalgamate customary, religious and statutory norms and practices are able to regulate land disputes in a way that challenges ideas that "state collapse and failure are tantamount to anarchy".53

An important question is whether these forms of public authority are locally desirable or more aptly described as locally present. It was about time that scholars and practitioners across the spectrum acknowledged the falsifying representations of the 'failed state' discourse, which tended to define conflictaffected and fragile places by what they lacked. ${ }^{54}$ At the same time, there is a risk, as Meagher points out, that rather than "overcome" the "essentialist tendencies" of the previous generation of informal governance literature, we "invert" these tendencies: "the condemnation of non-state order as institutionally destructive", she argues, "has been replaced by its celebration as a vehicle of embedded forms of order and authority". ${ }^{55}$ Various scholars have put forward typologies for distinguishing between what Meagher refers to as "con-

$51 \quad$ K. Menkhaus, 'Governance without Government in Somalia: Spoilers, State Building, and Politics of Coping', 31:3 International Security (2006/2007) p. 75.

52 See e.g., R. MacGinty and O. Richmond, 'The Local Turn in Peace Building: a Critical Agenda for Peace', 34:5 Third World Quarterly (2013) pp. 763-783.

53 T. Raeymakers et al., 'State and Non-State Regulation in African Protracted Crises: Governance Without Government?', 21:2 Afrika Focus (2008) p. 52.

54 Meagher, supra note 46, p. 1074.

55 Ibid. 
structive" and "corrosive" forms of non-state or hybrid order. At the heart of such calculations appear to be questions of legitimacy, public interest and broader conceptions of justice. Christian Lund, for example, highlights a voluntary compliance requirement and argues that in order for public authority to be legitimate, it must be reciprocal in nature and must be seen to be acting in the interests of the broader political community. ${ }^{56}$ In terms of justice provision, for example, it is argued that locally embedded forms of dispute resolution and reconciliation, normally delivered by non-state or hybrid public authorities provide an authentic and familiar environment through which popular participation can flourish. Kirk's article in this issue on East Timor points to the population's "limited knowledge of state justice institutions" and "heavy reliance on non-state justice institutions". Where formal systems are weak, absent or compromised, attempts to sustain viable forms of public mutuality may be relatively peaceful. As Hopwood (this issue) shows, discord and disagreement over land is a product of the customary system in northern Uganda and "negotiation is inherent in all land occupation and use" and is often conducted non-violently and through community forums.

It is important here to avoid what Kimberly Theidon calls a "facile embrace of the local". ${ }^{57}$ It is patently evident that public authorities and forms of hybrid governance can be violent, discriminatory and exclusionary. Indeed as Allen and Verweijen both demonstrate in this issue, vigilante executions, torture and mob violence are sometimes partly regarded as guarantors of 'public goods' that operate in the broader interests of community health, safety and harmony. Similarly Porter's study (this issue) demonstrates clearly how judicial avenues of redress after rape in northern Uganda and individual justice for the victim are often not pursued because of broader communal concerns about maintaining "social harmony". It should also be emphasised that the 'everyday' in local spaces is neither mundane, nor stable, nor uneventful. In most fragile and conflict-affected places, stark social deprivations and structural violence interfere regularly in daily life and in unpredictable ways. Drawing upon the work of Schmitt and Agamben some scholars have gone as far as to suggest that public authority, in essence, is fundamentally about defining exception and policing the constantly shifting boundaries between inclusion and exclusion from the political community. ${ }^{58}$ Particularly striking in this issue is the gendered dimension that such exclusion might take. Hopwood, Kirk and Porter

56 C. Lund, 'Twilight Institutions: Public Authority and Local Politics in Africa', 37:4 Development and Change (2006) p. 17.

57 K. Thiedon, 'Editorial Note', 3:3 International Journal of Transitional Justice (2009) p. 296.

$5^{8}$ Hoffman and Kirk, supra note 48, p. 15-17. 
in different ways, emphasise the gendered hierarchies that condition justice and accountability decisions, while Pendle and Verweijen depict a what has been referred in other contexts as a 'hegemonic masculinities discourse', a set of ideas and related actions that not only allows men to exercise control over women, but also over other men. ${ }^{59}$ It should be noted however, that these observations are often as relevant to the more formal and state-led judicial systems as they are to 'the local' in these contexts.

Of course local systems of social regulation and their defining characteristics, such as those described above, are never in stasis. An important point about hybrid forms of governance and public authority in conflict-affected and fragile places is that these are constantly shifting entities. Hybridity is not, as MacGinty points out, the grafting together of two or more calcified systems of political order. ${ }^{60}$ His concept of "prior hybridization" highlights the everadapting nature of governing systems and Pendle's portrayal of the evolving and shifting nature of the titweng in South Sudan is a good example of this, as is Allen's example of over-lapping and contradictory notions of accountability in Gulu, northern Uganda. Furthermore, as Hoffman and Kirk note, because public authority is influenced by the "ebb and flow of conflicts, contestations, competitions, negotiations and collaborative arrangements, it is never definitively formed", rather its capacity to exercise public authority is contingent on circumstances and even 'field,' such as 'security', or 'justice.' ${ }^{1}$

In conceptualising such processes, Lund's notion of 'twilight' institutions can be useful. He argues some institutions of public authority operate "in the twilight between the state and society, between public and private". ${ }^{62}$ As many authors have noted, these institutions, or authorities, often derive legitimacy from their ability to communicate a "language of stateness". ${ }^{63}$ They are, after all, as Migdal and Schlichte note, "doing the state" in some sense and thus while they exist and flourish because of it's relative absence, they also depend on its chimera as an anchoring logic. ${ }^{64}$ Allen and Reid have shown in the con-

59 C. Dolan, 'Collapsing Masculinities and Weak States - a case study of northern Uganda', in F. Cleaver (ed.) Masculinity Matters: Men, Masculinities and Gender Relations in Development (Zed Books, London, 2003).

6o R. MacGinty, 'Hybrid Peace: The Interaction Between Top-Down and Bottom-Up Peace', 41:4 Security Dialogue (2010) pp. 391-412.

61 Hoffman and Kirk, supra note 48, p. 10-11; Lund, supra note 56, p. 686.

62 Lund, supra note 56, p. 686.

63 Ibid., p. 677 .

64 J. Migdal and K. Schlichte, 'Rethinking the State', in K. Schlichte (ed.) The Dynamics of States: The Formation and Crises of State Domination (Ashgate Press, Aldershot, 2005) pp. $14-15$. 
text of the Madi district of north-western Uganda, how public authorities, in carrying out moral cleansing, can deploy the paraphernalia of the state, including "mimicking its procedural and symbolic forms of legitimacy" ${ }^{65}$ Here, local councils helped organise "witchcraft elections" including an election committee and communitywide voting by secret ballot, culminating in "semiformalized court hearings" as a means to "identify and expel those found guilty" from the community. Interestingly, this was described by Allen and Reid's informants as a "reaction to the inadequacy of existing legal mechanisms to deal with witchcraft accusations and as an effective deterrent to anti-social behavior" (those found guilty tended to be poor migrants and generally considered to be 'expendable') ${ }^{66}$ Here, echoing the election Allen describes in his article for this issue, it seems quite evident that informal groupings are producing power by drawing on recognised "symbols, rhetoric and institutional forms", a pattern noted elsewhere. ${ }^{67}$ There are other instances though, when the government itself is more closely involved in manipulating the non-state/state divide. Pendle, for example (this issue), shows how in South Sudan, after the 2010 elections, Sudan People's Liberation Army elites built 'loyal co-ethnic networks' through patronage of the titweng, who in turn, would protect their personal wealth in the form of cattle as well as "demonstrate their personal access to violence if needed".

Such concerns open up the important question of vested interests, power relations and connections between formal and informal modes of governance, including the provision of justice. Indeed, as Meagher asks, "in whose interest is the blurring of boundaries between formal and informal regulation, and what kinds of power relations underpin the shift of regulatory authority from formal to informal actors?". ${ }^{68}$ Scholars do need to be more historically attuned and forensically attentive to the precise power relations operating in any given context. Unless we locate the local in the context of national and global politics, and particularly in the globalised economy we risk over-localising analysis and misinterpreting the evidence. Doornbos, for example, makes the important distinction between "bottom up" systems of local order which may be

65 R. Tapscott, The State Has Long Hands: Community Security Groups and Arbitrary Governance in Acholiland (forthcoming).

66 T. Allen and K. Reid, 'Justice at the Margins: Witches, Poisoners, and Social Accountability in Northern Uganda', 34:2 Medical Anthropology (2015) pp. 115-116.

67 Tapscott, supra note 65. See also D. Pratten, 'The Thief Eats His Shame: Practice and Power in Nigerian Vigilantism', 78:1 Africa (2008) pp. 64-83; L. Buur, 'Re-Ordering Society: Vigilantism and Expressions of Sovereignty in Port Elizabeth's Townships', 37:4 Development and Change (2008) pp. 735-757. 
genuinely embedded in local systems of social regulation and appropriate procedure, and "proxy" arrangements, in which external actors have a powerful vested interest in co-opting or providing additional support to certain local groupings in order to further their own agendas. ${ }^{69}$ Such external actors can range from international donors involved in peace-building programmes, to neighbouring states, to foreign companies to national political elites. ${ }^{70}$ Indeed Alex de Waal's concept of the "political marketplace", the idea that in many fragile and conflict-affected places, political regimes can be seen as "businesses, including vertically-integrated criminal cartels, which produce both financial profit and political power for those individuals who rise within them and run them", correctly suggests that patronage politics is able to pervade the broader population through "militarized patrimonialism" and "identity politics." ${ }^{11}$ Indeed, the power relations at play in such an analysis should encourage us to interrogate more closely the existence of organic and "bottom up" approaches to the provision of public goods in such settings.

Questions of legitimacy and accountability are highly context specific and while it is true that informal and hybrid public authorities cannot be described "apriori as inherently good or bad for political legitimacy, governance or the degree of popular participation in it", scholars should continue to undertake the fine-grained field-based research that allows us to develop a clearer picture. ${ }^{72}$ Such efforts are also likely to uncover in more detail the appropriateness of applying Tillyan models - the idea that violence is linked to effective state formation - to modern fragile and conflict-affected places. Leander has pointed to several political and historical reasons why the Tillyan model, which is based on an analysis of state building in pre-modern Europe is not applicable to today's African states, including globalisation and external financial dependence. ${ }^{73}$ There is also a flawed teleology in understanding non-state or hybrid forms of life as an inevitable predicator of state formation, rather than as a distinctive way of understanding and interpreting moral governance and

69 M. Doornbos, 'Researching African Statehood Dynamics: Negotiability and Its Limits', 41:4 Development and Change (2010) pp. 747-69.

$70 \quad$ Meagher, supra note 46, p. 1082.

71 A. de Waal, 'The Political Marketplace: Developing a Framework for Addressing the Real Politics of Coercian and Corruption', Seminar Note, The Fletcher School of Law and Diplomacy, Tufts University (2014).

72 Kirk and Hoffmann, supra note 48, p. 19.

73 Meagher, supra note 46, p. 1078; A. Leander, 'War and the Un-Making of States: Taking Tilly Seriously in the Contemporary World', in S. Guzzini and D. Jung (eds.) Copenhagen Peace Research: Conceptual (Routledge, London, 2004). 
social order. ${ }^{74}$ Rather than treating hybrid public authority systems as a residual to be swept aside towards 'legitimate' formal institutions, they should be researched and analysed in their own right.

4

\section{Doing Justice?}

So far we have discussed 'law', 'order' and the various authorities that mediate and deliver it. But what about justice? Because although justice is commonly associated with law, the "application of law does not always produce justice" for those at the receiving end. ${ }^{75}$ This can be as true of local laws and rules as it is of state law. The articles in this special edition indirectly add substance to the broader theoretical debate between liberalism and communitarianism that has been raging since the 1980 s. In depicting various micro-level instantiations of the experience of public authority (both as exercised directly by the State and by other authorities and institutions), and providing some assessment of how 'just' people perceive their treatment (and that of others) to be, a very complicated picture emerges. Not surprisingly it challenges liberal assertions that there is one vision of justice, that can be abstracted from context and exists as 'universally true', based on liberal, democratic values. It also, however, challenges the more communitarian position that standards of justice are highly context specific and depend entirely on the interpretative framework within which people and communities view their world. ${ }^{76}$ In all of our articles we see people rejecting the notion of the sovereign state applying principles of justice through the application of formal laws; but we also see people rejecting or expressing discomfort with more locally grounded efforts to regulate moral and social life.

What becomes apparent is the existence of a highly complex conglomerate of interests - ranging from the daily management of material assets, to the need to regulate moral order, to the need to maintain geographical and political boundaries. Arguably the assemblage of these concerns comprises something called a 'community': what Etzioni famously described as "webs of social relations that encompass shared meanings and above all shared values", but

74 Dresch, supra note 4, p. 14-15

75 Pirie and Scheele, supra note 28, p. 1.

76 For an example of the communitarian position, even if they did not refer to themselves as 'communitarians', see C. Taylor, Philosophy and the Human Sciences: Philosophical Papers (Cambridge University Press, Cambridge, 1985) Chapter 1; A. MacIntyre, Whose Justice? Which Rationality? (Notre Dame University Press, Notre Dame, 1988). 
the idea of the 'community' is under-theorised in fragile and conflict-affected spaces, and Pirie and Scheele are right to question the assumption that communities are naturally bounded: "Although terms and values may be broadly shared, sometimes across a wide area, they are actualised among people one knows". ${ }^{77}$ As Baker and Scheye point out, in post-conflict and fragile states:

People are rarely users of either private or public agencies, as if these were mutually exclusive categories. In post-conflict and fragile states and indeed in most developing states, their choices, in as much as they have them, are based on 'what is available', 'what works best' and 'what can I afford', more than issues of who controls the agency and to whom they are accountable. People shop around for the type of security and justice they want. ${ }^{78}$

This perhaps over-emphasises the choices available to people in difficult settings, but it allows us to depart from the more deterministic interpretations of justice conceptions as either 'universally true', or as culturally determined. Rather it encourages us to think about a more Sen inspired "arrangement focused" theory of justice, which aims to understand the "advancement or retreat of justice" by asking not what "perfectly just institutions" might look like, but rather "how would justice be advanced?" in any given context. ${ }^{79}$

There are, argues Sen, two basic and divergent approaches to thinking about justice. Both took shape in the enlightenment period, and continue to influence our reasoning today. The first is what he calls "transcendental institutionalism". 80 This is the approach taken by philosophers as diverse as Thomas Hobbes, Jean Jacques Rousseau, and Immanuel Kant, who were preoccupied with setting out institutional arrangements that would create the most just society. The focus of this tradition was on "perfect justice", and on "getting the institutions right", and while much thought was given to the "requirements of behavioral norms" to ensure compliance, this line of inquiry focused on desirable rather than actual behaviors and social interactions". ${ }^{81}$ Sen distinguishes between "transcendental institutionalism" and what he terms "realiza-

77 Pirie and Scheele, supra note 28, p. 14.

78 B. Baker and E. Scheye, 'Multi-Layered Justice and Security Delivery in Post-Conflict and Fragile States', 7:4 Conflict, Security and Development (2007) p. 515.

79 A. Sen, The Idea of Justice (Penguin Books, London, 2009) pp. 8-9.

8 o Ibid., p. 5 .

81 Ibid., pp. $5^{-6 .}$ 
tion based comparison".82 The latter, he argues, was the approach taken by thinkers with substantive theories as diverse as Adam Smith, John Stewart Mill, and Karl Marx. Instead of focusing on the attainment of a transcendental and perfectly just society, they were interested in "societies that already existed or could feasibly emerge". ${ }^{33}$ Despite the apparent relevance of such an approach to the legally pluralistic and hybrid societies of today's fragile and conflict-affected places, it is the first approach, "transcendental institutionalism", characterised as it is by a strongly positivistic trend, which shapes much of the scholarship and practice of contemporary development policy in this area. ${ }^{84}$

As the discussion above illustrates, even though there are over-arching legal and normative justice concepts at the international level, this does not translate into "reasoned agreement on the nature of the just society", and, moreover, the search for such agreement is probably elusive, or as Sen would argue, redundant. Indeed there exists in the literature some debate about the need for sounder conceptual architecture to help us understand and even 'operationalise' notions such as justice. Two successive United Nations SecretaryGenerals, Kofi Annan and Ban Ki Moon have referred to the need to "articulate a common language of justice" in their reports on transitional justice and the rule of law. ${ }^{85}$ Justice, however, exists as a 'notion' rather than a discrete goal and will probably never have a universal meaning. There will always be multiple 'conceptions' of what justice is. In many places the very word 'justice' has no direct translation, and even where it does, individual and group ideas about what justice actually means can range from access to healthcare to the ability to pay school fees or for a decent burial. Geoff Dancy has written about the tendency of scholars, even those working from an interpretative perspective, to "self-reflexively' base judgments about justice in any given context on a "maximalist position", which dictates that justice "must be universal, equal and color blind". ${ }^{86}$ Departing from such an approach does not amount to a call for

$82 \quad$ Ibid., p. 7 .

83 Ibid.

84 K. McAvoy, 'Beyond Legalism: Towards a Thicker Understanding of Transitional Justice', 34:4Journal of Law and Society (2007) p. 415.

85 See United Nations Secretary-General, 'The Rule of Law and Transitional Justice in Conflict and Post-Conflict Societies:Report of the Secretary General to the Security Council' (s/2004/616); United Nations Secretary-General, The Rule of Law and Transitional Justice in Conflict and Post-Conflict Societies: Report of the Secretary General to the Security Council (s/2011/634).

86 G. Dancy, 'Impact Assessment, Not Evaluation: Defining a Limited Role for Positivism in the Study of Transitional Justice', 4:3 International Journal of Transitional Justice (2010) p. 369 . 
methodological cultural relativism. It is an argument for a practical approach, which takes into account imperfect realities, and seeks to acknowledge, interpret and reflect on the plurality of different justice-related claims and principles that exist in fragile and conflict-affected settings and how, and why, some arrangements are understood as just, while others are perceived as unjust. ${ }^{87}$

Let us take post-conflict northern Uganda as an example of this dilemma. As Julian Hopwood argues in this volume, the vast majority of people affected by land disputes since the closure of the displacement camps, turn to local leaders for mediation rather than to magistrates' courts for adjudication. There are many historical and political reasons why this may be the case. Aside from a general lack of trust in state authorities to rule fairly and efficiently, Macdonald has pointed to a recurrent theme in post-conflict northern Uganda, which is that people grapple with the 'generality' of formal laws and their apparent universality because these properties stand in tension with the highly place and circumstance specific way in which rightful order is maintained. ${ }^{88}$ Porter, in this issue and elsewhere, points to another tension which is that among the Acholi, the "primary moral imperative in the wake of wrongdoing is not punishment of the perpetrator or individual victim's rights, but the restoration of social harmony". ${ }^{99}$ Porter describes social harmony as "a state of normal relations among the living and the dead, linked to an idea of cosmological equilibrium and a social balance of power and moral order". ${ }^{90}$ Thus, in the context of rape, for example, the appropriate response is not dependent solely on the act of forced sex, but crucially on the "social role of the perpetrator"; the "social context" in which that act took place and the broader implications that punishment might have on social harmony. This does not preclude a desire for justice as a legal process amongst those individuals who have been wronged, but because social harmony is such a "highly valued ideal", those individuals often express either a coerced or a willing acceptance that this type of justice may not materialise or will remain a secondary concern.

For the detached 'liberal' observer these dynamics will induce discomfort. There is concern that in mediating the tension between the universality of

$87 \quad$ Sen, supra note 79, p. 9 .

88 Macdonald, supra note 41. See also Scheele and Pirie, supra note 28. Scheele and Pirie point out that Aristotle and Cicero both wrote about the tension between the universality of the law and the peculiarity of particular cases and in ancient times, rulers were often judged on their ability to negotiate a fair path between the latitudinous requirements of general rules and the particular circumstances of individual cases.

89 Porter, supra note 8, p. 15 .

9o Ibid. 
rules and the particularity of specific cases, the opportunities for manipulation are rife. Furthermore, there is a concern that in prioritising communal harmony over individual redress, those who are particularly vulnerable (such as the woman who has been raped), will always be denied self-actualisation. For supporters of a more 'local' justice in northern Uganda, the argument holds that certain leaders have a "moral jurisdiction" which confers upon them the discretionary power to apply the law in a way that is circumstance specific. ${ }^{91}$ This fluidity and adaptability is understood as a great bonus. ${ }^{92}$ But if we, as researchers, can parachute down from the latitudinous perspectives of those who are for and those who are against different justice arrangements and into the empirical, lived reality of those who experience and negotiate different rules, codes of conduct and standards on a daily basis, we can begin to get a sense of "actual realizations and accomplishments" and of substance over form. ${ }^{93}$ Thus we can probably conclude that for the woman in Porter's study who had been raped by her late husband's nephew and infected by HIV aids, justice was not done. She wanted her relatives to contact the police, and she wanted the perpetrator imprisoned, but in the interests of social harmony, this was not done and the victim understood the constraints imposed on her by her environment: "no good Acholi would pursue justice alone". On the other hand, for Barbara, the women studied by Hopwood, who was subject to a land dispute initiated by her nephew who claimed that as a woman, she "had no rights to own land", justice was probably done. Clan elders and local councillors settled the case in favour of Barbara and even though her nephew refused to accept the decision, "all the community members" supported Barbara. Coming back to Sen, such divergent findings in one socio-political space should encourage an analysis of justice that is empirically grounded and focused not simply on how institutions should look and what general rules should comprise, but also on, "what emerges in the society, including the kinds of lives that people can actually lead, given the institutions and rules, but also other influences, including actual behavior that would inescapably affect human lives". ${ }^{94}$

In exploring the complexity of people's ideas and social arrangements, such an approach has the possibility of making significant contributions to

\footnotetext{
$91 \quad$ Ibid., p. 112.

92 Martin Chanock famously wrote of the way in which the very flexibility of 'rules' was gave customary systems their 'essence' in the African context. See M. Chanock, Law, Custom and Social Order: The Colonial Experience in Malawi and Zambia (Pearson, London, 1985). Sen, supra note 79, p. 10.

Ibid., p. 10.
} 
comparative and theoretical debates about justice and authority in fragile and conflict-affected places.

\section{$5 \quad$ Rule of Law as Theatre and Fantasy}

We turn now to arguments about rule of law. Rule of law programmes are implemented as part of development assistance packages in every country under study in this issue. These programmes target the reform of state level arrangements, but are also designed to make customary, hybrid and local justice practices more 'legible' and palatable to an international audience. In practice as Humphrey's has noted, they take on aspects that might be described as theatrical - "a morality tale about the good life",95 and they are driven by fantastical normative agendas that bear little connection with the lived realities of political authority and social accountability in targeted populations. Based on specific ideas of what rule of law might look like grounded in Weberian conceptions critiqued above, the specific policies introduced might include funding for the training of judges; the codification of customary laws in line with international standards; or the 'sensitisation' of elders in fundamental freedoms that the international community promotes such as the rights of minorities and the rights of individuals. Along with other initiatives such as security sector reform (SSR) and disarmament, demobilisation and reintegration (DDR), rule of law strengthening has become a core component of what MacGinty terms "routine peace-building", and another element of the "common swirl of politically related 'good things' that development and aid agencies see as central in the promotion of liberal market democracies in post conflict states". ${ }^{96}$ The 'rule of law' itself is a notoriously difficult concept to pin down. Querying the precise meaning of the term has almost become a scholarly sub-discipline in itself but Balakrishnan Rajagopal's summation that it is "increasingly seen as the panacea for all the problems that afflict many non-Western countries, particularly in post-conflict settings" is apt. He continues:

95 S. Humphreys, Theatre of the Rule of Law: Transnational Legal Intervention in Theory and Practice (Cambridge University Press, Cambridge, 2012) p. xxii.

96 R. MacGinty, 'Routine Peace: Technocracy and Peacebuilding', 47:3 Cooperation and Conflict (2012) pp. 287-308; T. Carothers and D. De Gramont, Development Aid Confronts Politics: The Almost Revolution (Carnegie Endowment for International Peace, Washington, D.C., 2013) p. 57. 
Development experts prescribe it as the surest shortcut to market-led growth; human rights groups advocate the rule-of-law as the best defense against human rights abuses; and in the area of peace and security, the rule of law is considered the surest guarantee against the re-emergence of conflict. ${ }^{97}$

Despite the highly political nature of these outcomes, the prevailing approach among both development theorists and practitioners has been a paragon of what Kurki refers to as "depoliticised, instrumental and technical" forms of intervention, which rely on supplanting successful legal models across contexts. ${ }^{98}$ The rhetoric around rule of law policy and programming is politically neutralised, using the language of 'good governance' which is presented as intuitive, or 'post-political' and thus non-contestable. The reality is that to invoke the rule of law is "always to take a position on the ordering of society", but its promotion also tends to "forestall political possibilities" because of a focus on structural and procedural reforms that often bypass legislative processes. ${ }^{99}$ The problem is that such interventions, or "massive social engineering exercises" have, to date, been both highly costly and notably ineffective. ${ }^{100}$ State legal systems, such that they exist in all of the contexts under study in this volume, remain defective and non-state and hybrid systems continue to function widely and often in a way that may offend liberal sensibilities. There are many reasons why this might be the case. Below, we highlight two that are central.

Firstly, the normative structures that exist in global politics are not selfevidently true. Questions about why and how states adhere to them reveal what Schmitt famously called the "political quality of the law".101 President Museveni's quip to the audience at the 2010 Review Conference in Kampala about "you people" and "your love of human rights!" was disconcerting for observers and it is tempting to caricature his remarks as playful deviance or pure politicking. ${ }^{102}$ This would be misguided. As Nick Cheesman has argued, too often, scholars and practitioners have misconstrued the gap between

97 B. Rajagopal, 'Invoking the Rule of Law in Post-Conflict Rebuilding: A Critical Examination', 49:4 William and Mary Law Review (2007) pp. 1347-1348.

98 M. Kurki, 'Human Rights and Democracy Promotion: Reflections on the Contestation in, and the Politico-Economic Dynamics of, Rights Promotion', 32:2 Third World Quarterly (2011) pp. 1573-1587.

99 Humphreys, supra note 95, pp. xv-xvi.

100 Sage and Woolcock, supra note 5, p. 5; Raeymakers et. al, supra note 53, p. 2.

101 C. Schmidtt, Constitutional Theory (Duke University Press, Durham, 2008) p. 30.

102 Macdonald, supra note 41. 
compliance and commitment as a gap between "principle and practice, between aspiration and reality", when the issue is actually that governments in question are being held up to an "ideal to which they do not in fact subscribe". ${ }^{103}$ Thus the difference in political arrangements is not just one of "degree" but of "kind", a realisation that should "encourage a little less hubris" and more sober attention to the possibility that states and leaders who do not subscribe to the rule of law are not simply "occupants of low rungs on a ladder to the rule of law, they are climbing a different ladder altogether".104 Indeed as de Waal argues, the "political marketplace is not a transitional or outdated system that is about to be replaced by Weberian states, but a flexible and dynamic governance order". ${ }^{105}$ Thus where rule of law programmes are implemented by governments, they fail or fail to thrive in many contexts because they represent straightforward "isomorphic mimicry", that is "governments and organisations pretend to reform by changing what policies or organisations look like rather than what they actually $d o^{\prime 1}{ }^{106}$ In many situations, this leads to a bizarre process of structural disassociation, particularly by development officials. Indeed, de Waal recalls a meeting with an individual who worked for an international organisation in Somalia, who told him:

International officials in Somalia spent their office hours working on systems and procedures that they knew were a fantastical construction, and in the evening they secretly read the papers of political analysts to find out what was really going on - like clandestine users of pornography. Meanwhile, any Somali officials who spoke publicly about the 'real politics' of the country ... would be treated as if they were breaking the rules of acceptable behavior. ${ }^{107}$

Secondly, in Humphrey's tracing of the genealogy of the rule of law he points out that as classically conceived, the concept described the "normative base or legitimacy of the law in force" (emphasis added). The notion of the rule of law therefore derived its legitimacy from the community subjected to it: the rule of law, he argues, was, "intended to express a minimal

\footnotetext{
103 N. Cheesman, 'Law and Order as Asymmetrical Opposites to the Rule of Law', 6:1 Hague Journal on the Rule of Law (2014) p. 113-114.

104 Ibid.

105 de Waal, supra note 71, p. 2.

106 M. Andrews et al., 'Escaping Capability Traps Through Problem-Driven Iterative Adaptation', 299 Centre for Global Development (2012) p. 1.

107 de Waal, supra note 71, p. 2.
} 
societal consensus or "deal" about "the rules of the game". ${ }^{108}$ External interventions rarely acknowledge the pervasively complicated nature of the systems that people already use. Rather these systems are regarded as defective or problematic, outdated or corrupt and transformable via technical and externally devised 'rule of law' solutions. ${ }^{109}$ The often tokenistic but widespread provision for local "ownership" and "sensitization" around reforms "merely underlines this structural reality".110 There is a problematic assumption that function will flow from form, i.e., that what a system does, will flow naturally from what it looks like. ${ }^{111}$

There are, argue Caroline Sage and Michael Woolcock, who lead the World Bank's Justice for the Poor programme, clear "organisational imperatives" in large development agencies, which combine to shape and cement such an approach. ${ }^{112}$ Development professionals, they argue, tend to view the rule of law as a "variant on other familiar technical problems" such as road building or crop fertilisation, which can be designed and implemented by external 'experts' and consultants. ${ }^{13}$ Moreover, the bureaucratic structure of these institutions demand that certain protocols be followed, including project documents with measurable indicators, matrices that "deftly link together aspects of social life" and a persuasive story about how change will happen in a given time frame of usually three to five years. ${ }^{114}$ None of this takes into account Geertz's well-known call in the 1980 s for a hermeneutic approach to the study of law across cultures, rather than a functional one: "meaning, not machinery", he argued, was the category to be explored. ${ }^{115}$ There are few opportunities or career incentives for development professionals to engage in the anthropological, sociological or historical analysis that is more attuned to the "inherently relational and inherently contested nature of socioeconomic life". ${ }^{116}$ Such analysis, which by its very nature is deeply contextual, is like to reveal something rather obvious: that legal orders are fundamentally about putting in place the rules and parameters that direct and regulate political and social relationships. By extension, interventions aimed at transforming such relation-

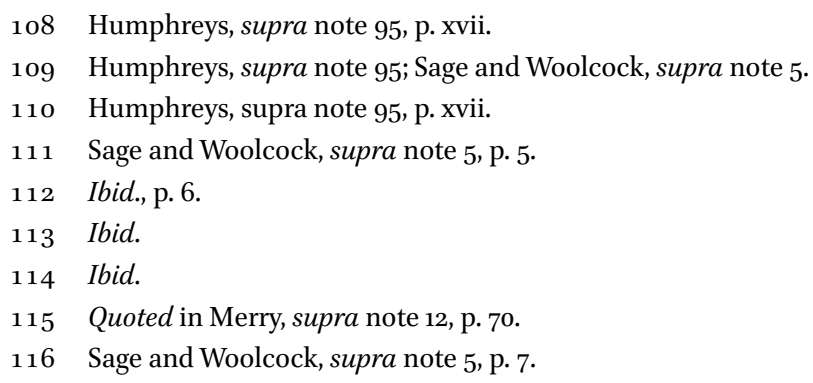


ships via institutional reform or normative shifts threaten the existing status quo and as such are likely to be highly contentious. This is as true at the state level as it is at the most local level.

In this context, it is hardly surprising that the women in Porter's study (this issue) who had been raped recognised that they had 'rights' because they had been informed of them by NGOs, but did not access the services on offer because of the clear social norm that relatives and elders remained the "primary sources of decision making on responding to rape". But it is not simply the case the people are always constrained by their social circumstances. Indeed Hopwood's study of land dispute resolution in the same context points out that people rarely turn to courts for adjudication, and, as in other examples, women are sometimes liberated from sexually violent and neglectful marriages by caring in-laws and relatives. The Ugandan government's postconflict strategy for the north, which is funded largely through donors, is to promote formal justice structures and to consolidate 'state authority' into the sub-region. This involves building more magistrates courts, more police stations, and more prisons, and all the while 'sensitising' the population to what these institutions are and how they should be used. This logic is central to donor support for rule of law promotion, the idea being that if judicial capacities are increased and people are 'trained' and 'educated' in what proper legal systems really look like, then the rule of law will be strengthened. But individuals and communities are not just generic 'users' who make decisions separable from their social contexts. ${ }^{117}$ Pre-existing and reified institutions concerned with the rule of law, such as the police and the courts, acquire meaning through history, and through the shared meaning systems that generate contest and redefine them. ${ }^{118}$ This is not to say that rule of law interventions are doomed to failure, rather it is to point out that these must be understood as deeply complex social and political interventions, which rely on the 'acquiesence' and voluntary compliance of those they are designed to benefit.

Perhaps in loose recognition of this, traditional and indigenous processes are currently receiving ever more attention in both state-building and counterinsurgency policy, while, in some contexts, putative traditional governance systems are being foregrounded in a manner that has not happened since the era of colonial indirect rule. It is believed that embedding orthodox peacebuilding approaches in local culture will enhance their legitimacy and efficacy,

\footnotetext{
117 V. Gauri et al., 'Intersubjective Meaning and Collective Action in Developing Societies: Theory, Evidence and Policy Implications', 49:1 Journal of Development Studies (2013) p. 116.

118 Ibid.
} 
thereby providing an authentic and familiar environment through which popular participation might begin to flourish. As one United Nations Development Programme report notes: "existence of these systems cannot be overlooked. We need to develop strategies to take advantage of the benefits of informal systems". ${ }^{119}$ The World Bank's 2011 World Development (WRD) Report, Conflict, Security and Development, marks an important step towards recognising the scale and complexity of the challenges of governance in difficult places. Ultimately though, the central message is the need to strengthen "legitimate institutions" in order to provide citizens with security and development. Although the WDR insists that such institutions need not be based on a western model, it implies that only exceptionally will they deviate. Additionally, although the WDR stresses that the process of building such institutions will require multiple moments of transition, and visually models the process as a spiral, it implies that progress must (and eventually will) take a unidirectional path. The report notes that supplementing formal justice with traditional community systems can be a "best fit"; but with a revealing caveat: "The lesson here appears to be to use a process of recognition and reform to draw on the capacities of traditional community structures and to 'pull' them gradually in the direction of respect for equity and international norms.". 120 Selective support for 'traditional' or 'customary' justice here provides a sort of indigenous anchor: a means by which the broader, donor supported agendas around transitional justice, access to justice and rule of law promotion can be grounded, authenticated and legitimised.

It would be disingenuous to suggest that the issues identified above are not recognised by policy makers and practitioners as a problem. On the margins of mainstream development policy making there are other approaches that are being trialled. Kirk (this issue) points to the emergent framing of particularly difficult development challenges as arising from collective action problems that can only be addressed by citizens and governments working collaboratively. This approach does not expurgate a role for outsiders, instead, it recommends that they abandon the preconception that elites and citizens of developing countries have developmental orientations hard-wired into them and stresses a need to understand, in detail, local political incentive structures to make change happen. As such, it cites the potential of outsiders to "encourage 'practical hybrids'; conceived of as strategies that combine local repertoires,

\footnotetext{
119 E. Wojkowska, Doing Justice: How Informal Systems Can Contribute (United Nations Development Programme, New York, 2006) p. 13.

120 World Development Report 2011: Conflict, Security and Development (World Bank, Washington DC, 2011) p. 167 .
} 
social norms and moral economies with imported and tested governance practices". Kirk points to a legal empowerment programme in Timor-Leste, that was funded by an international NGO and was implemented largely by local legal aid lawyers and paralegals who were able to provide access to justice to victims of domestic violence. While this gave people a means of accessing justice of some sort, hybridity also led to unintended outcomes, including suspended sentences for domestic violence following reconciliation ceremonies, that have the potential to be beneficial or non-beneficial on a case-by-case basis.

The conclusion that development interventions need to be more 'context sensitive' is well worn, and so are efforts at describing how policy interventions that are context sensitive might be framed and put into practice. One current such effort is the emerging 'doing development differently' literature.121 Influenced by the regrettably jargonistic term "problem-driven iterative adaption" (PIDA), the thinking behind the approach is said to stand in "stark contrast" to development orthodoxies despite articulating things that most agencies already claim to be doing. ${ }^{12}$ The four-fold approach includes solving locally nominated and defined problems; creating an environment that encourages 'positive deviance' and experimentation in practice; allowing for "rapid experiential learning" rather than relying on ex-post 'evaluations'; and finally, engaging a wide range of actors to ensure that reforms are "viable, legitimate, relevant and supportable". ${ }^{123}$ There is an explicit understanding here that the devil will always be in the detail and that simplistic indicators and cross-country technical solutions are a blunt and ineffective development tool. Efforts are being made to apply this approach to local realities of law and justice and to give researched populations a voice. We have of course been here before. The World Banks's Voices of the Poor Programme for example, began in the late 199os and in 2004 one of us interviewed many World Bank officials about what had been learned from the programme so far. Most said that they were not quite sure what to do with the information and one, a leading econo-

121 See e.g., L. Wild et al., Adapting Development: Improving Services to the Poor (Overseas Development Institute, London, 2015).

122 M. Andrews et. al., supra note 106. For a critique, see M. Greenall, Doing Aid Differently, 17 March 2015, <hepidreamiology.wordpress.com/2015/03/17/doing-differently/>, visited on 23 March 2015.

123 Andrews et. al., supra note 106. 
mist, was more explicit: he said that the World Bank had learnt that poor people were ignorant. More recently, one of us interviewed a senior policy official of a large donor agency in Kampala, responsible for programming transitional justice funding. She complained that too much time is wasted on consultations with affected communities: "the problem is, we are consulting people on things they do not know about. Without being educated, how can they know what the best policy is for them?" It remains to be seen over ten years later whether highlighting the realities of lived experience will make much difference. The research programme of which the articles collected here are a part is one of many initiatives aimed at trying to make it so: they focus on the complexities of specific circumstances. ${ }^{124}$ The project now for us and others is to frame them in a rigorously comparative manner to fundamentally shift the terms of debate.

124 The Justice and Security Research Programme (JSRP) is an international research consortium based in the Department of International Development at the London School of Economics, with funding with the U K Department for International Development (DFID). 